International Journal of Health Sciences
Available online at www.sciencescholar.us
Vol. 5 No. 1, April 2021. pages: 29-37
ISSN: 2550-6978 E-ISSN: 2550-696X
https://doi.org/10.29332/ijhs.55n1.725

\title{
High Antioxidant Level in Cajanus sajan Reduces Blood Glucose Level and Improves Blood Lipid Profile of Rats as Diabetes Mellitus Models
}

\author{
Yuli Laraeni ${ }^{1}$, I Gusti Ayu Nyoman Danuyanti ${ }^{2}$, Ersandhi Resnhaleksmana ${ }^{3}$, Iswari Pauzi ${ }^{4}$, I Komang \\ Agusjaya Mataram ${ }^{5}$, Ni Putu Agustini ${ }^{6}$
}

Manuscript submitted: 27 November 2020, Manuscript revised: 09 December 2020, Accepted for publication: 18 January 2021

*Corresponding Author

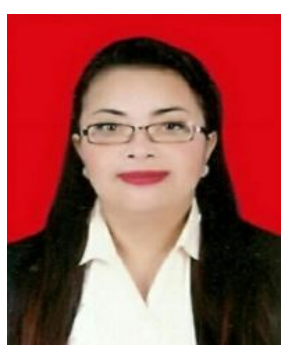

\section{Keywords}

blood glucose;

cholesterol;

lipid profile;

pigeon bean tempe;

triglycerides;

\begin{abstract}
Hyperglycemia in DM was able to increase glucose auto-oxidation, protein glycation, and polyol pathway activation. As a result, it can accelerate the formation of reactive oxygen compounds acting as the main factor causing DM complication. Before we evaluated pigeon bean Tempe with formulations of $25 \%, 50 \%$, and $75 \%$, we tested the number and activity of its antioxidant. Then we substituted it on standard feed for 14 days to find the effects on glucose level and lipid profile. The effects were then compared to that before the intervention. The result showed that the total and activity of antioxidants in pigeon bean Tempe (Cajanus sajan) was 15\% and $41.30 \%$ respectively. On the other side, pigeon bean Tempe with a formulation of $75 \%$ was more able to reduce blood glucose level, total cholesterol, triglycerides, and LDL-cholesterol by $44.08 \%, 34.38 \%, 35.80 \%$, and $43.22 \%$ respectively $(\mathrm{p}<0.05)$ if compared to pigeon bean Tempe with formulations of $25 \%$ and $50 \%$. Meanwhile, pigeon bean Tempe with the formulation of $75 \%$ provided better effects for an increase of HDL level $56.20 \%(\mathrm{p}<0.05)$. All test results on Tempe formulation used were compared to that before the intervention.
\end{abstract}

International Journal of Health Sciences (C) 2021.

This is an open access article under the CC BY-NC-ND license (https://creativecommons.org/licenses/by-nc-nd/4.0/).

\footnotetext{
${ }^{1}$ Department of Nutrition, Mataram Health Polytechnic, Indonesia

${ }^{2}$ Departement of Medical Laboratory Technology, Mataram Health Polytechnic, Indonesia

${ }^{3}$ Departement of Medical Laboratory Technology, Mataram Health Polytechnic, Indonesia

${ }^{4}$ Departement of Medical Laboratory Technology, Mataram Health Polytechnic, Indonesia

${ }^{5}$ Department of Nutrition, Denpasar Health Polytechnic, Indonesia

${ }^{6}$ Department of Nutrition, Denpasar Health Polytechnic, Indonesia
} 


\begin{tabular}{|c|c|c|}
\hline \multicolumn{3}{|c|}{ Contents } \\
\hline & stract & 29 \\
\hline & Introduction ............................ & 30 \\
\hline & Materials and Methods... & 31 \\
\hline 3 & Results and Discussions ........................ & 32 \\
\hline & 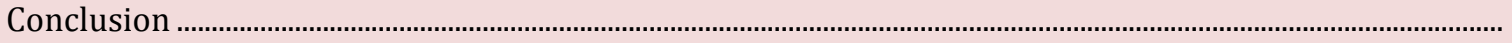 & 34 \\
\hline & 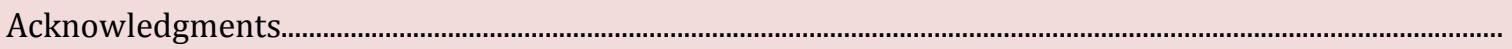 & 34 \\
\hline & 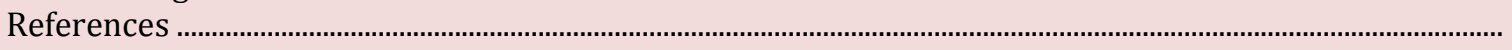 & 35 \\
\hline & Biography of Authors & 37 \\
\hline
\end{tabular}

\section{Introduction}

Diabetes mellitus is a group of carbohydrate, lipid, and protein metabolic diseases characterized by hyperglycemia due to absolute or relative insulin deficiency. Hyperglycemia can increase glucose autooxidant, protein glycation, and poliyol pathway activation. It accelerates the formation of reactive oxygen compounds as the main factor causing DM complication. It is due to imbalanced cellular antioxidant defense capacity; such as superoxide dismutase (SOD), glutathione peroxidase, and catalase from oxidative damage (Packer et al., 2000; Naudi et al., 2012).

The prevalence of DM always increases every year. In 2000, the number of people suffering from DM was estimated at around 171 million and predicted to increase to 336 million in 2030 (Wild et al., 2004). Basic Healthy Research data (2013) shows that the prevalence of DM in Mataram is quite higher if compared to that in other regions in NTB that was $1.7 \%$. Based on data from Mataram Health Office, there were 1689 cases related to DM in 2013 and (January-December) and 1653 in 2014 (January-November). It shows that DM cases, particularly in Mataram are still quite high.

Hyperglycemia condition also affects the transports of triglycerides and cholesterol in the circulation and tissue. Decreased insulin production disrupts enzymes important for metabolism; such as lipoprotein lipase enzyme and hormone-sensitive lipase. As a consequence, fat level in the circulation increases, but decreases in the adipose tissue. It will increase lipid peroxidation and trigger oxidative stress in people with DM (Tjokroprawiro, 2003; Inawati et al., 2006). Hence it is necessary to obtain DM treatment and management.

DM treatment can be carried out optimally by combining nutritional therapy, physical activities, and medication. Nutritional therapy is considered the most effective therapy, especially for the onset of DM. Nutritional interventions used in DM therapy are carbohydrate counting, decreased energy intake, and selection of functional foods providing positive effects for the development of DM (Franz \& Alison, 2012). Functional food contains bioactive components i.e. micronutrients (selenium, zinc, vitamin C, vitamin D, and calcium), fiber, antioxidants, and prebiotics. Dietary fiber food, especially soluble dietary fiber food has functions to control the levels of cholesterol and glucose and gives physiological effects on glucose regulation (Hirsch \& Brownlee, 2005; Kim et al., 2006; Partama et al., 2018). The food has a high viscosity that can slower glucose, cholesterol, and triglyceride absorption in the small intestine. Exogenous antioxidants from functional food have functioned as coenzyme interacting and synergizing with cellular antioxidants to protect the body from free radical damage (Maritim et al., 2003; Tensiska, 2009). The selection of functional food is expected to be found from local food, such as pigeon bean Tempe (Cajanus sajan), easing to find and process it.

Pigeon beans (Cajanus sajan) are a source of anthocyanin pigments; such as cyanidin-3-glucoside and delphinidin-3-glucoside that can reduce cholesterol levels and are functioned as antioxidants. In this research, pigeon beans were processed into Tempe using Tempe yeast (Rhizopus $s p$ ), hence a daily consumption. Besides, it is also used as nutritional therapy for people with DM. Pigeon beans processed into Tempe are inspired by a local business in Lombok, particularly in Mataram. People there produce Tempe and tofu from soybeans. However, the research used gude beans with lower carbohydrates and fat than soybeans. In addition to that, pigeon beans have never been widely produced as functional food providing positive effects especially for people with DM (Haliza, 2009; Nurrahman et al., 2012).

We selected pigeon beans in the form of tempe because, after the fermentation process, Tempe gave more advantages than unprocessed tempe. In terms of nutrient composition in general, Tempe has a higher digestibility of protein and essential amino acid, lower anti-nutritional substances; such as antitrypsin and 
phytic acid, and decomposing enzymes that digest protein, fat, and carbohydrate more easily. Besides, it contains genistein and daidzein, isoflavones serving as antioxidants to increase cellular antioxidant activities. The significance of using pigeon beans as tempe is that the beans have lower carbohydrate and fat than Tempe made of soybean. Therefore, it is good to be consumed by people with DM (Nurrahman et al., 2012).

Pigeon beans in West Nusa Tenggara are only used as processed vegetables combined with other vegetables with a distinctive and favored taste. Furthermore, the beans contain not only higher anthocyanins, but also higher glutamate amino acid than soybeans, making the food more savory. Therefore, in addition to nutritional therapy, gude beans can be widely produced as a local business, especially in Mataram. The result of previous research shows that the use of black soy yogurt can reduce the levels of cholesterol, triglyceride, and HDL of white rats with hypercholesterolemia. It also shows that the use of purple sweet potatoes with a $10 \%$ concentration can reduce the effects of free radicals caused by liver necrosis on rats given paracetamol and maximum activity load (Jawi et al., 2008). Meanwhile, we emphasize the use of local food, Tempe as a functional food. Before given to the rats with DM, Tempe had been tested. We conducted a proximate test to find the levels of carbohydrate, lipid, and protein; soluble and insoluble fiber tests; resistant starch level test; and test on the activity as well as the capacity of antioxidant Tempe produced contained. Therefore, it is expected that Tempe can be used as an alternative nutritional therapy, especially for the management of glucose and lipid profiles in people with DM.

\section{Materials and Methods}

Pigeon bean Tempe

The Process of Pigeon bean Tempe (Cajanus sajan) Production (Nurrahman et al., 2012)

Firstly, foreign objects mixed with pigeon beans were removed. Then, the beans were washed using clean water and boiled for 30 minutes before skinned and soaked for 36 hours. Soaked pigeon beans were drained and steamed for one hour. Finally, the beans were inoculated with tempe yeast $(2 \%)$ and incubated at $25-27^{\circ} \mathrm{C}$ for 36 hours (Figure 1).

The Test on Activity and Total Antioxidant in Pigeon Tempe (Cajanus sajan)

Antioxidant activity in pigeon Tempe was measured using the 1.1-Diphenyl-2-picrylhidrazyl (DPPH) method; while the total antioxidant was analyzed using the colorimetric method with FRAP Ferric reducing activity potential (FRAP) (Xu \& Chang, 2007; Selawa et al., 2013).

\section{Experimental Animals and Diets}

Experimental animals used were 25 Wistar white rats (Rattus norvegicus) (eight weeks old, 80-22 g) obtained from Immunology Laboratory University Mataram. The research had been approved by the Ethics Commission of Faculty of Medicine, University Mataram (Approval Number: 56/UN18.8/ETIK/2016). All experimental animals were categorized into five groups i.e. normal rats (N), rats with DM (P1), rats with DM + pigeon beans with a formulation of $25 \%$ (P2), rats with DM + pigeon beans with a formulation of $50 \%$ (P3), and rats with DM + pigeon beans with a formulation of 75\% (P4). P1, P2, P3, and P4 groups were injected with low dozed streptozotocin (STZ) and Nicotinamide (NA) for seven days intraperitoneally. The rats were considered hypertriglyceridemic if they had glucose levels in plasma $>100 \mathrm{mg} / \mathrm{dL}$. Pigeon bean Tempe was given with standard food (AIN93) in certain formulations to achieve isocaloric. The standard food combined with $25 \%, 50 \%$, and $75 \%$ calorie formulations was served in pigeon bean Tempe calculated based on the result of proximate analysis test (See Table1).

Laraeni, Y., Danuyanti, I. G. A. N., Resnhaleksmana, E., Pauzi, I., Mataram, I. K. A., \& Agustini, N. P. (2021). High antioxidant level in cajanus sajan reduces blood glucose level and improves blood lipid profile of rats as diabetes mellitus models. International Journal of Health Sciences, 5(1), 29-37. https://doi.org/10.29332/ijhs.v5n1.725 
Table 1

Calculation of the Formulation of Pigeon Bean Tempe with Standard Diet AIN 93 (g/kg Rat Weight) Given to Rats with DM

\begin{tabular}{llrrrr}
\hline & Ingredient & \multirow{3}{*}{ Standard Diet } & \multicolumn{3}{c}{ Tempe Diet } \\
\cline { 3 - 5 } & & 140 & $50 \%$ & $75 \%$ \\
\hline 1. & Casein & 620.7 & 605.94 & 591.18 & 576.42 \\
2. & Corn starch & 0 & 69.63 & 139.25 & 208.88 \\
3. & Tempe flour & 42.79 & 31.71 & 21.15 & 10.57 \\
4. & Corn oil & 100 & 100 & 100 & 100 \\
5. & Sucrose & 50 & 46.35 & 42.70 & 39.05 \\
6. & CMC & 10 & 10 & 10 & 10 \\
7. & Vitamin mix AIN93 & 35 & 35 & 35 & 35 \\
8. & Mineral mix AIN 93 & 1.8 & 1.8 & 1.8 & 1.8 \\
9. & L-cystin & 2.5 & 2.5 & 2.5 & 2.5 \\
\hline 10. & Choline bitartrate & & &
\end{tabular}

Nurrahman et al., 2012

Rats with DM (P2, P3, P4) were given pigeon bean Tempe with formulations of 25\%, 50\%, and 74\% for 14 days. During the intervention, N group (normal control) and P1 (DM control) were given standard food for 14 days.

\section{Analysis of the Levels of Glucose and Lipid Profile in Blood}

The analysis of the levels of glucose and lipid profile (triglycerides, total cholesterol, LDL-cholesterol, and HDL-cholesterol) was performed after the rats were given the formulations for 14 days (Warabi et al., 2004; Attie et al., 2002). The result was then compared to that of the result given by the rats that did not obtain any formulation. Moreover, glucose and lipid profiles were measured using the enzymatic colorimetric method with Kit Dialysis.

\section{Results and Discussions}

The Examination on Total Antioxidant and Activities of Pigeon Bean Tempe (Cajanus sajan)

The result of the test on antioxidant activities of pigeon bean Tempe was 15\%; while its total antioxidant and anthocyanin level were $41.30 \%$ and of $65.58 \mathrm{ppm} / 100 \mathrm{~g}$ sample respectively. By high active substances (antioxidant) of pigeon bean Tempe the result showed, we could use it as a choice of processed food. Also, it created an opportunity to make local food more profitable.

The Measurement of the Level of Glucose and Lipid Profile in Rats with DM Before and After the Intervention of Pigeon Bean Tempe (Cajanus sajan)

The result of the measurement of the levels of glucose and lipid profile in rats with DM after the intervention of pigeon bean tempe formulation for 14 days showed a decrease lower than that before DM intervention and control $(\mathrm{p}<0.05)$. The measurement results before and after the intervention of pigeon bean tempe in rats with DM are presented in Table 2. 
Table 2

The level of glucose and lipid profile in Rats with DM before and after the intervention of Pigeon Bean Tempe

\begin{tabular}{|c|c|c|c|c|c|c|c|c|c|c|}
\hline \multirow[t]{2}{*}{ Treatments } & \multicolumn{5}{|c|}{$\begin{array}{l}\text { Before Pigeon bean tempe } \\
\text { administration }(\mathrm{mg} / \mathrm{dl})\end{array}$} & \multicolumn{5}{|c|}{$\begin{array}{l}\text { After Pigeon bean tempe administration } \\
(\mathrm{mg} / \mathrm{dl})\end{array}$} \\
\hline & Glu & Chol & $\mathrm{Tg}$ & HDL & LDL & Glu & Chol & $\mathrm{Tg}$ & HDL & LDL \\
\hline t0 & 67.75 & 82.44 & 91.09 & 66.30 & 30.80 & 67.77 & 85.66 & 92.38 & 65.61 & 31.91 \\
\hline $\mathrm{t} 1$ & 214.12 & 177.04 & 131.09 & 25.33 & 71.52 & 216.25 & 178.81 & 132.24 & 24.70 & 74.22 \\
\hline $\mathrm{t} 2$ & 216.11 & 171.00 & 133.28 & 25.47 & 69.90 & 157.10 & 143.56 & 114.16 & 37.58 & 67.87 \\
\hline t3 & 219.39 & 171.13 & 136.64 & 25.61 & 73.80 & 133.07 & 126.94 & 97.51 & 58.08 & 44.19 \\
\hline $\mathrm{t} 4$ & 222.67 & 177.46 & 134.16 & 25.88 & 72.46 & 124.52 & 112.51 & 86.12 & 59.09 & 41.14 \\
\hline
\end{tabular}

Data are shown as mean $(\mathrm{n}=5)$

Glu : Blood Glucose

Chol : Total of Cholesterol

Tg : Triglycerides

LDL : Low Density Lipoprotein

HDL : High Density Lipoprotein

t0 : Normal rats + standard diet

t1 : Rats with DM + standard diet

t2 : Rats with DM + pigeon beans tempe with a formulation of $25 \%$

t3 : Rats with $\mathrm{DM}+$ pigeon beans tempe with a formulation of $50 \%$

t4 : Rats with DM + pigeon beans tempe with a formulation of $75 \%$

The intervention of pigeon bean tempe with a formulation of $75 \%$ more effectively reduced the levels of glucose, cholesterol total, triglyceride, and LDL_cholesterol by $44.08 \%, 34.38 \%, 35.80 \%$, and $43.22 \%$ respectively $(\mathrm{p}<0.05)$ than pigeon bean Tempe with formulations of $25 \%$ and $50 \%$. Also, pigeon bean Tempe with a formulation of $75 \%$ provided better effects for the increase of HDL level that was $56.20 \%(p<0.05)$. All results of the examination on Tempe formulation used was compared to that before the intervention.

\section{Discussion}

Total antioxidants and their activities of pigeon bean (Cajanus sajan) tempe respectively were $15 \%$ and 41.30\%. 2.2-Diphenil-1-picrylhidrazil (DPPH) test was effective to measure the antioxidant activity of gude beans able to keep free radicals away. During a hyperglycemic condition, free radicals increased. Hence external additional antioxidant that could be obtained by consuming dietary food was required. Pigeon bean tempe contained high antioxidant $41.30 \%$ and activities $15 \%$. Consuming antioxidants from dietary food would help cellular antioxidant activity prevent the glucose antioxidant process known as a cause of increased production of free radicals and inhibit advanced glycation end products (AGEs) to bind with their specific receptor (RAGE). It could inhibit the formation of free radicals that spurred oxidative stress crucial for pathogenesis and complication on DM (Elmarakby et al., 2012; Karunakaran \& Keun-Gyu, 2013).

Hyperglycemic conditions due to STZ and NA inductions led to glucose auto-oxidant, protein glycation, and poliyol pathway activation, accelerating the formation of free radicals. The formation of free radicals was able to increase lipid, DNA, and protein modification in various tissues. It could eventually cause oxidative stress that led to a complication on people with DM (Nuttal et al., 1999). Table 2.shown the level of glucose considerably declining after the intervention of pigeon bean tempe with a formulation of $75 \%$. It was because the high fiber level of pigeon beans inhibited glucose absorption by blood vessels, inhibiting the rate of the increase of glucose level. It supported previous research stating that the intervention of Gracilaria verrucosa extracts with a high fiber level in different doses was able to reduce glucose level in white rats (Candratama et al., 2012). Decreased glucose level was also because of high antioxidant level and activity in pigeon bean tempe able to minimize the formation of AGEs in the polyol pathway. As a result, the enzymatic glycation process was suppressed. Antioxidant was an electron-donor compound inhibiting oxidation reaction by binding free radicals with highly reactive molecules, so lipid peroxidation as one of cell damage causes could be prevented. By consuming antioxidants from dietary food, the function of cellular antioxidants would

Laraeni, Y., Danuyanti, I. G. A. N., Resnhaleksmana, E., Pauzi, I., Mataram, I. K. A., \& Agustini, N. P. (2021). High antioxidant level in cajanus sajan reduces blood glucose level and improves blood lipid profile of rats as diabetes mellitus models. International Journal of Health Sciences, 5(1), 29-37. https://doi.org/10.29332/ijhs.v5n1.725 
be balanced. Therefore, it could provide protective effects on DM by reducing lipid peroxidation and Nitrite Oxide (NO) production and increasing cellular antioxidant activities (Coskun et al., 2005; Dykes et al., 2006).

Our research result also showed a more decreased lipid profile level; such as total cholesterol, triglyceride, and low-density lipoprotein (LDL), and increased high-density lipoprotein (HDL). The highest decrease and increase in lipid profile were found in the intervention of pigeon bean Tempe with a formulation of 75\%. It was because the fermentation process in pigeon beans reduced both fat and carbohydrate levels in pigeon bean Tempe and slowed down glucose absorption due to high fiber levels. Therefore, glucose production declining decreased triglyceride level as fat reserves.

In DM cases, the consumption of pigeon beans with high antioxidants was able to increase cellular antioxidant activity that could prevent lipid peroxidation to reduce oxidative stress as one of the complications causes in people with DM (Coskun et al., 2005; Dykes et al., 2006). The result of our research and the previous research also stated that flavonoid level or high antioxidant type, as well as high fiber in dietary food, were able to prevent lipid peroxidation and reduce glucose level in DM-conditioned or hyperlipidemic-conditioned experimental animals (Setyawan et al., 2005; Isdamayani \& Panunggal, 2015).

\section{Conclusion}

High total antioxidant and its activity of pigeon bean (Cajanus sajan)Tempe were able to reduce glucose level and improve lipid profile in rats with DM. The intervention of pigeon Tempe with a formulation of $75 \%$ provided better effects than that with formulations of $25 \%$ and $50 \%$.

\section{Acknowledgments}

This research was supported by Mataram Health Polytechnic and Human Resources Development and Empowerment Agency, Ministry of the Health Republic of Indonesia. 


\section{References}

Attie, A. D., Krauss, R. M., Gray-Keller, M. P., Brownlie, A., Miyazaki, M., Kastelein, J. J., ... \& Ntambi, J. M. (2002). Relationship between stearoyl-CoA desaturase activity and plasma triglycerides in human and mouse hypertriglyceridemia. Journal of lipid research, 43(11), 1899-1907. https://doi.org/10.1194/jlr.M200189JLR200

Candra Tama, S.A., Dewi, E. N., \& Ibrahim, R. (2012). The Effect of Gracilaria verrucosa Extract Feeding to the Blood Glucose Content of White Rats (Rattus norvegicus). Saintek Perikanan: Indonesian Journal of Fisheries Science and Technology, 8(1), 1-6.

Chang JH., Min SK., Tae WK., Sang SL (2008). Effect of Soybean Suplementation on Blood Glucose, Plasma Lipid Levels, and Erythrocyte Antioxidant Enzyme Activity in Type 2 Diabetes Mellitus Patients. NRP 2(3): 152157.

Coskun, O., Kanter, M., Korkmaz, A., \& Oter, S. (2005). Quercetin, a flavonoid antioxidant, prevents and protects streptozotocin-induced oxidative stress and $\beta$-cell damage in rat pancreas. Pharmacological research, 51(2), 117-123. https://doi.org/10.1016/j.phrs.2004.06.002

Dykes, L., \& Rooney, L. W. (2006). Sorghum and millet phenols and antioxidants. Journal of cereal science, 44(3), 236-251. https://doi.org/10.1016/j.jcs.2006.06.007

Elmarakby, A. A., Faulkner, J., Baban, B., Saleh, M. A., \& Sullivan, J. C. (2012). Induction of hemeoxygenase-1 reduces glomerular injury and apoptosis in diabetic spontaneously hypertensive rats. American Journal of Physiology-Renal Physiology, 302(7), F791-F800.

Frans, M.J., \& Allison, B.E. (2012). American Diabetes Association Guide for Nutrition Terapy for Diabetes second edition. American Diabetes Association, USA.

Haliza, W. (2008). Without Soybeans, You Can Still Eat Tempe. Center for Post-Harvest Agricultural Research and Development, Bogor.

Hirsch, I. B., \& Brownlee, M. (2005). Should minimal blood glucose variability become the gold standard of glycemic control?.Journal of Diabetes and its Complications, 19(3), 178-181. https://doi.org/10.1016/j.jdiacomp.2004.10.001

Inawati, Syamsudin, \& Winarno, H. (2006). Effect of Leaf Extract of Henna (Lawsonia inermis Linn) on Decreasing Levels of Glucose, Total Cholesterol, and Blood Triglycerides of Mice Induced by Aloksan.jki1 (2): 71-7.

Isdamayani, L., \& Panunggal, B. (2015). Kandungan flavonoid, total fenol, dan antioksidan snack bar sorgum sebagai alternatif makanan selingan penderita diabetes mellitus tipe 2 (Doctoral dissertation, Diponegoro University).

Jawi, I. M., Suprapta, D. N., \& Subawa, A. N. (2008). The Extract of Purple Sweet Potato Decrease Blood and Liver Mda of Mice after Intense Physical Activity. Jurnal Veteriner, 9(2).

Karunakaran, U., \& Park, K. G. (2013). A systematic review of oxidative s

Kim, S. H., Hyun, S. H., \& Choung, S. Y. (2006). Anti-diabetic effect of cinnamon extract on blood glucose in $\mathrm{db} / \mathrm{db}$ mice. Journal of ethnopharmacology, 104(1-2), 119-123. https://doi.org/10.1016/j.jep.2005.08.059

Maritim, A. C., Sanders, A., \& Watkins Iii, J. B. (2003). Diabetes, oxidative stress, and antioxidants: a review. Journal of biochemical and molecular toxicology, 17(1), 24-38.

Naudi, A., Jove, M., Ayala, V., Cassanye, A., Serrano, J., Gonzalo, H., ... \& Pamplona, R. (2012). Cellular dysfunction in diabetes as maladaptive response to mitochondrial oxidative stress. Experimental diabetes research, 2012.

Nurrahman, Astuti, N., Suparmo, Marsetyawan, H.N.E.S. (2012). The Role of Black Soybean Tempe in Increasing Antioxidant Enzymes and Resistance of Rat Limpocytes to Hydrogen Peroxide In Vivo. Seminar on Research Results, LPPM Unimus.

Nuttall, S. L., Dunne, F., Kendall, M. J., \& Martin, U. (1999). Age-independent oxidative stress in elderly patients with non-insulin-dependent diabetes mellitus. Qjm, 92(1), 33-38.

Packer, L., Peter R., Hans J,T., George L,K.,,Angelo, (2000). Antioxidant in Diabetic Managemet. Marcel Dekker, Inc, New York.

Partama, I. B. G., Yadnya, T. G. B., Trisnadewi, A. A. A. S., \& Sukada, I. K. (2018). Fermented rice husk utilization of effective microorganisms-4 supplemented with Piper betle L. performance, meat quality, antioxidant capacity, and meat cholesterol levels of Bali duck. International Journal of Life Sciences, 2(3), 98-110.

Laraeni, Y., Danuyanti, I. G. A. N., Resnhaleksmana, E., Pauzi, I., Mataram, I. K. A., \& Agustini, N. P. (2021). High antioxidant level in cajanus sajan reduces blood glucose level and improves blood lipid profile of rats as diabetes mellitus models. International Journal of Health Sciences, 5(1), 29-37. https://doi.org/10.29332/ijhs.v5n1.725 
Selawa, W., Runtuwene, M. R., \& Citraningtyas, G. (2013). Kandungan flavonoid dan kapasitas antioksidan total ekstrak etanol daun binahong [Anredera cordifolia (Ten.) Steenis.]. Pharmacon, 2(1).

Setiawan, B., Suhartono, E., \& Mashuri, M. (2005). Kajian Stress Oksidatif Pada Bayi Prematur. Mutiara Medika: Jurnal Kedokteran dan Kesehatan, 5(1), 27-35.

Tensiska. (2009). Food fiber. Scientific Libraries, Univ. Padjadjaran.

Tjokroprawiro, A. (2003). Diabetes mellitus: kelasifikasi, diagnosis dan terapi. Gramedia Pustaka Utama.

Warabi, Y., Kusdiana, D., \& Saka, S. (2004). Reactivity of triglycerides and fatty acids of rapeseed oil in supercritical alcohols. Bioresource technology, 91(3), 283-287. https://doi.org/10.1016/S09608524(03)00202-5

Wild, S., Roglic, G., Green, A., Sicree, R., \& King, H. (2004). Global prevalence of diabetes: estimates for the year 2000 and projections for 2030. Diabetes care, 27(5), 1047-1053.

Xu, B. J., \& Chang, S. K. C. (2007). A comparative study on phenolic profiles and antioxidant activities of legumes as affected by extraction solvents. Journal of food science, 72(2), S159-S166. 


\section{Biography of Authors}

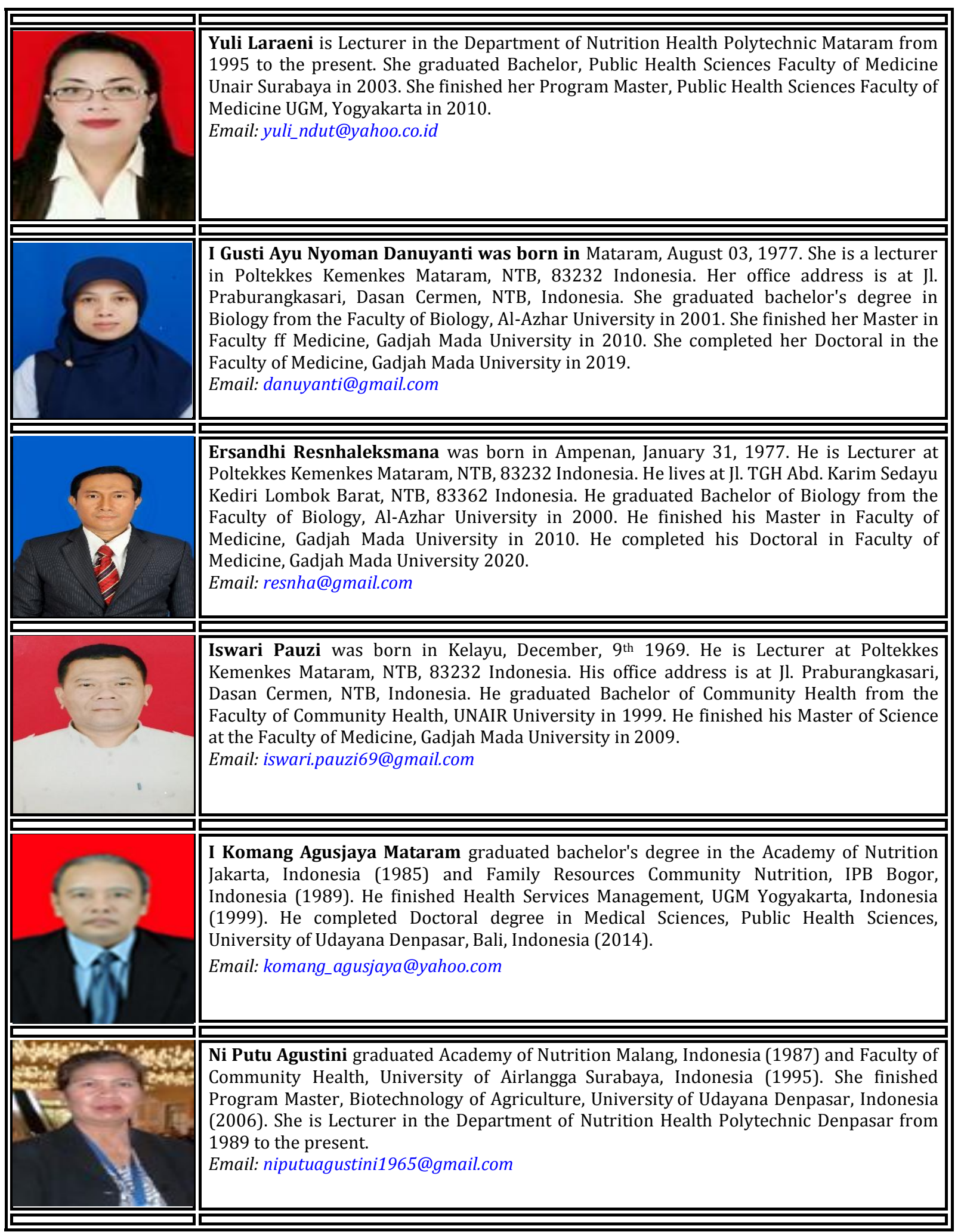

Laraeni, Y., Danuyanti, I. G. A. N., Resnhaleksmana, E., Pauzi, I., Mataram, I. K. A., \& Agustini, N. P. (2021). High antioxidant level in cajanus sajan reduces blood glucose level and improves blood lipid profile of rats as diabetes mellitus models. International Journal of Health Sciences, 5(1), 29-37. https://doi.org/10.29332/ijhs.v5n1.725 